ATOMICS INTERNATIONAL

A Division of North American Aviation, Inc.

\title{
NAA-SR-MEMO -5238
}

This document contains 7 pages

Do not remove this sheet

This is copy of series

\section{UNCLASSIFIED}

Security Classification

\section{NAA-SR-MEMOs are working papers and may be expanded, modified, or withdraun at any time, and are intended for internal use only.}

This report may not be published without the approval of the Patent Branch, AEC. *

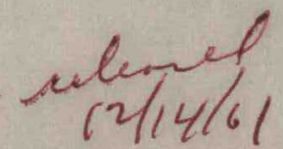

\section{LEGAL NOTICE}

This report was prepared as an account of Government sponsored work. Neither the United States, nor the Commission, nor any person acting on behalf of the Commission:

A. Makes any warranty or representation, express or implied, with respect to the accuracy, completeness, or usefulness of the information contained in this report, or that the use of any information, apparatus, method, or process disclosed in this report may not infringe privately owned rights; or

B. Assumes any liabilities with respect to the use of, or for damages resulting from the use of information, apparatus, method, or process disclosed in this report.

As used in the above, "person acting on behalf of the Commission" includes any om. ployee or contractor of the Commission to the extent that such employee or contractor prepares, handles or distributes, or provides access to, any information pursuant to his employment or contract with the Commission. 


\section{DISCLAIMER}

Portions of this document may be illegible in electronic image products. Images are produced from the best available original document. 


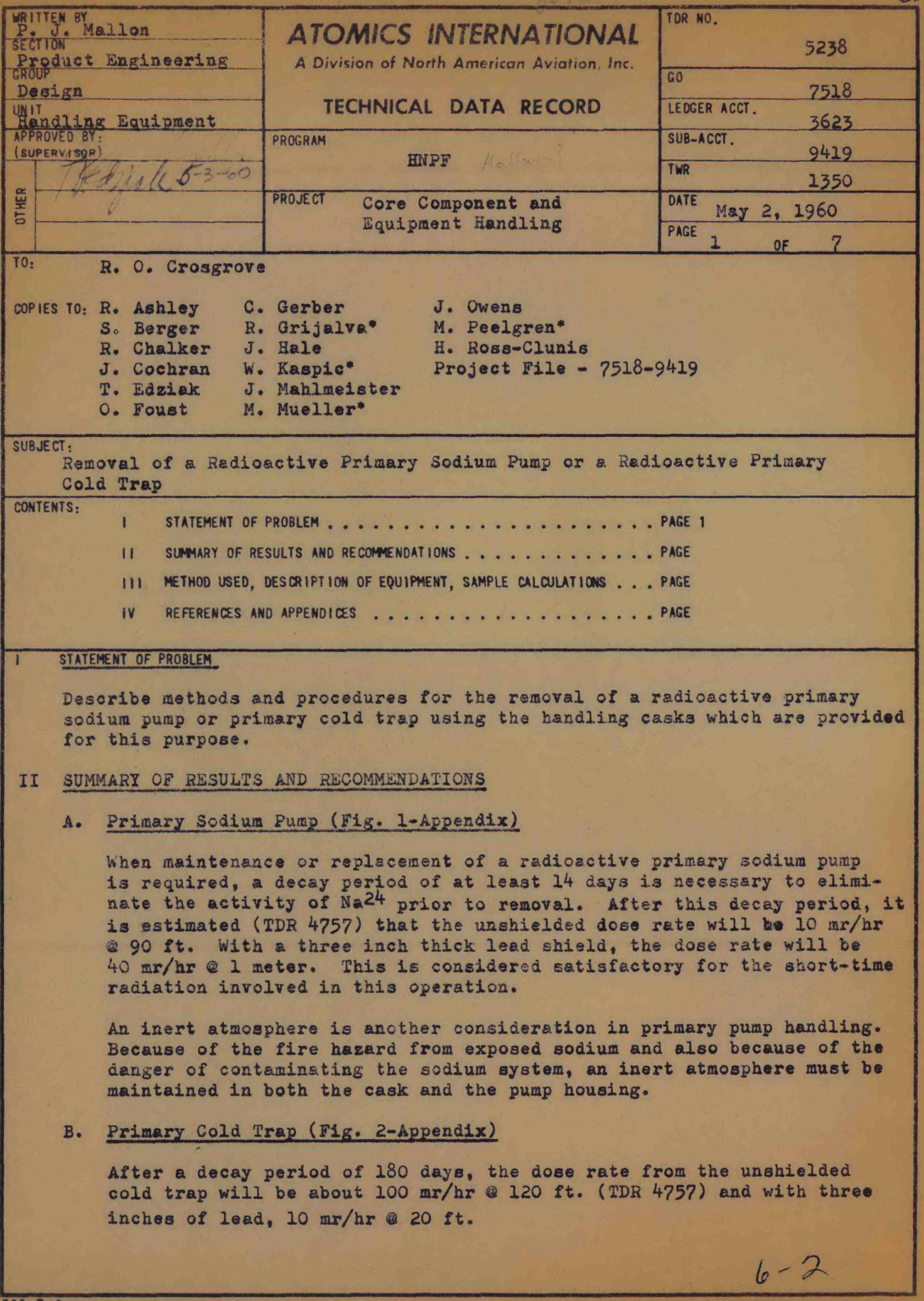


Fire danger from any exposed sodium in the cold trap coll makes it necessary to maintain an inert atmosphere in the cell and also in the cask.

\section{DESCRIPTION OF EQUIPMENT AND HANDLING METHODS}

\section{A. Primary Pump Handling Equipment}

The primary pump handling equipment consists of an upper shell and a lower shield tube, a bail assembly, a grapple adapter, an electro-magnetic shield plate lifter assembly, two shield plate assemblies, and extension rods.

\section{B. Method of Handling the Primary Pump}

As shown in Fig. 1-(Appendix), the pump assembly consists of a drive motor and coupling; the pump; and pump housing. Only the pump is handled by the cask.

The following sequence is to be followed in radioactive pump removal (Fig. 1).

1. Remove drive motor and coupling. (Fig. 1-a)

2. Purge the purap with argon gas until all the belium in the pump has been replaced.

3. Bolt the grapple adapter in place. (Fig. 1-b)

4. Unbolt the pump from the base plate at the floor line.

5. Locate pump handling cask over the pump, and purge the cask with nitrogen gas.

6. Attach extension rods to grapples and the bail assembly to extension rods.

7. Lower grapples with crane and engage in grapple adapters. $(F \perp g \cdot i-c)$

8. Raise pump into the cask and secure in "up" position with pins through grapples. (Fig. l-d)

9. Detach extension rods from grapples, and unhook bail from crane.

10. Ifft pump and cask about one inch from floor, slide shield plates under cask, and set cask down on plates.

11. Energize electro-magnets, and pick up pump cask and top shield plate, and move to pump wash cell. (Fig. I-e) 


DATE $\frac{\text { MaY 2, } 2960}{\text { PAGE } 3 \text { OF ? }}$

12. After wash eycle is complete, lift pump into cask and secure grapples. Remove extension shafts, E-M pick-up ring, and shield plate; and move cask and pump to storage, Maintenance Shop, or Shipping Dopartment.

C. Primary Cold Trap Handling Equipment

The primary cold trap handling equipment consist of an upper shield cap and a shield tube, a bail assembly, and theplate lifter assembly.

\section{Method of Handling Primary Cold Trap}

During normal operation, the cold trap is mounted in a tilted position at $5^{\circ}$ from vertical, the pivot point $?^{\prime \prime}$ off the centerline of the cell.

A single flanged connection near the top of the cold trap provides both the sodium inlet and outlet connections. The vessel plange and the system flange are "made up" with a Vee band clamp. The clamp is fitted with two screws remotely controlled by means of flexible shafts. The shafts terminate with hex ends in a recess in the floor near the cell. A standard socket with handle is used to drive the clamp shafts.

An insulated shield encloses the cold trap. The upper part of this shield is a hinged clam shell which is remotely controlled with a flexible shaft. This shaft also ends in a recess in the floor adjacent to the cold trap cell.

A toggle linkage, remotely controlled, is used to move the cold trap from the $5^{\circ}$ tilted position to the upright position required for removal. This toggle is strong enough to break any frozen sodium which might remain at the connection between the trap and the primary sodium system.

Calculations (TDR 4757) show a high dose rate even after a decay period of 180 days. With a stend-by cold trap in the sodium system, it is assumed that the full 180-day decay period will be allowed before the spent trap will be removed.

The sequence for cold trap removal (Fig. 2) is as follows.

1. Close inlet and outlet sodium valves to the spent cold trap. and open the valves to the Btand-by cold trap.

2. After 180 days (to permit decay) remove covers from the remote control access boxes.

3. Using the remote controls, loosen the Vee clamp on the sodium connection llange. 
4. Remotely open the clam shell shield.

5. Tilt the cold trap to vertical position using the tilt toggle.

6. Using the crane, lift the cell plug just enough to slide a pit cover plate over the cell.

7. Move the cell plug to temporary storage, and pick up the cold trap handling cask.

8. Locate the cask (the E-M plate lifter and magnetic cover plate in place on the bottom of the cask) over the centerlines of the cold trap.

9. Purge the cask with nitrogen, lift approximately one inch, and withdraw magnetic and pit cover plates. Relocate the cask.

10. Attach extension rod and bail assembly to the grapple, remove the lock pin, lower bayonet-type grapple, and engage in piekup socket on the cold trap.

11. Lift cold trap into "up" position in cask, replace lock pin, remore extension rod and bail.

12. Pick up cask and cold trap approximately one inch, relocate cover sheet and magnetic sheet.

13. Replace the cask, energize the electro-magnets.

14. Move cask cold trap electro-magnetic plate pick-up and the magnetic plate to the storage location.

15. Remove cover sheet, clean cell thoroughly, install new cold trap, replace plug, and purge cell with argon gas.

IV REFERENCES AND APPENDICES

1. TDR 4757 - W. A. Rhondes - December 15, 1959

2. Drawing No. 7518-D74147 Primary Pump Handling Cask Assembly

3. Drawing No. 7518-D74151 Bail Assembly - Primary Pump Lifting

4. Drawling No. 7518-D74154 Electromagnetic Shield Plate Iffter Assembly

5. Drawing No. 7518-D74131-5 Shield Plates and $-I I$

6. Drawing No. 7518-D74104-7 Extension Rods 


NO $\frac{5238}{\operatorname{May} 2,1960}$
DATE $\frac{5}{5}$ OF ?

IV RETERENCES AND APPENDICES (CONT'D)

7. Drawing No. 7518-D74153 Cold Trap Handling Cask

8. Drawing No. 7518-D74152 Bail Assembly - Cold Trap Handiling

9. Drawing No. 7518-D74155 Grapple Adapter - Pump 
-

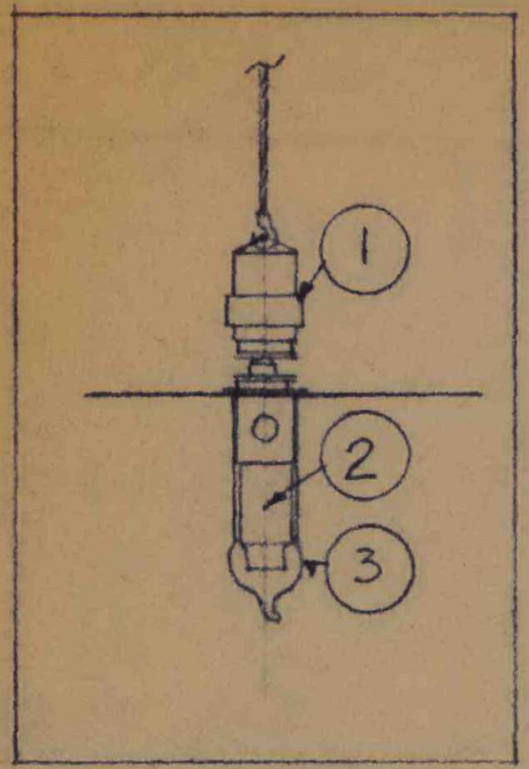

a

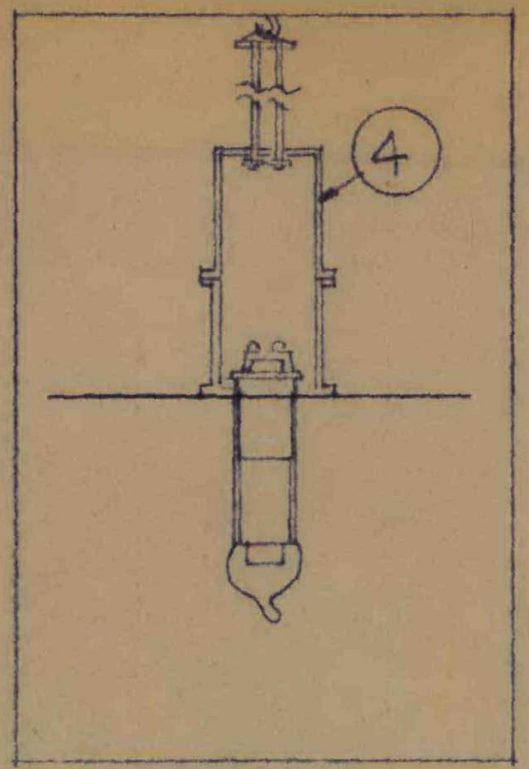

b

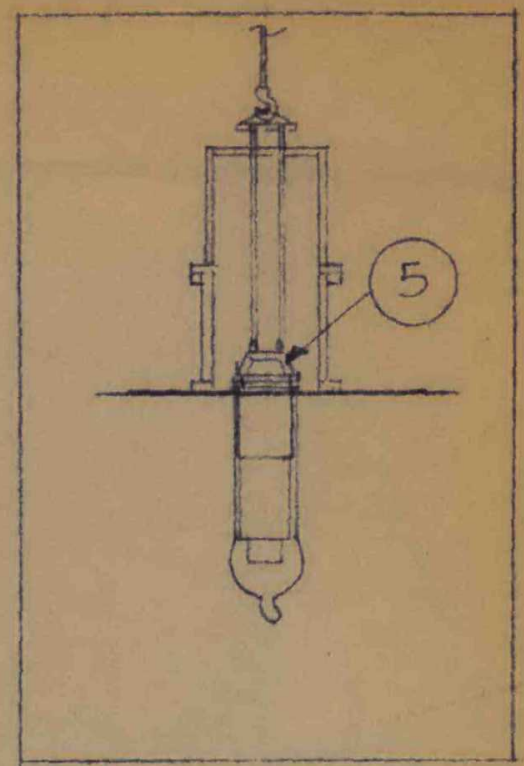

C

LEGEND

1-MOTOR-COUPLING

2-PUMP

3-PUMPHOUSING

4-CASK

5-GRAPPLE ADAPTER

6-CRANE
7.- ELECTRO-MAGNET ASSEMBLY. 8-GRAPPLE \& LIFT FIXTURE 9- PLUG 10-WASH CELL

11-CASK LIFT RIGGING
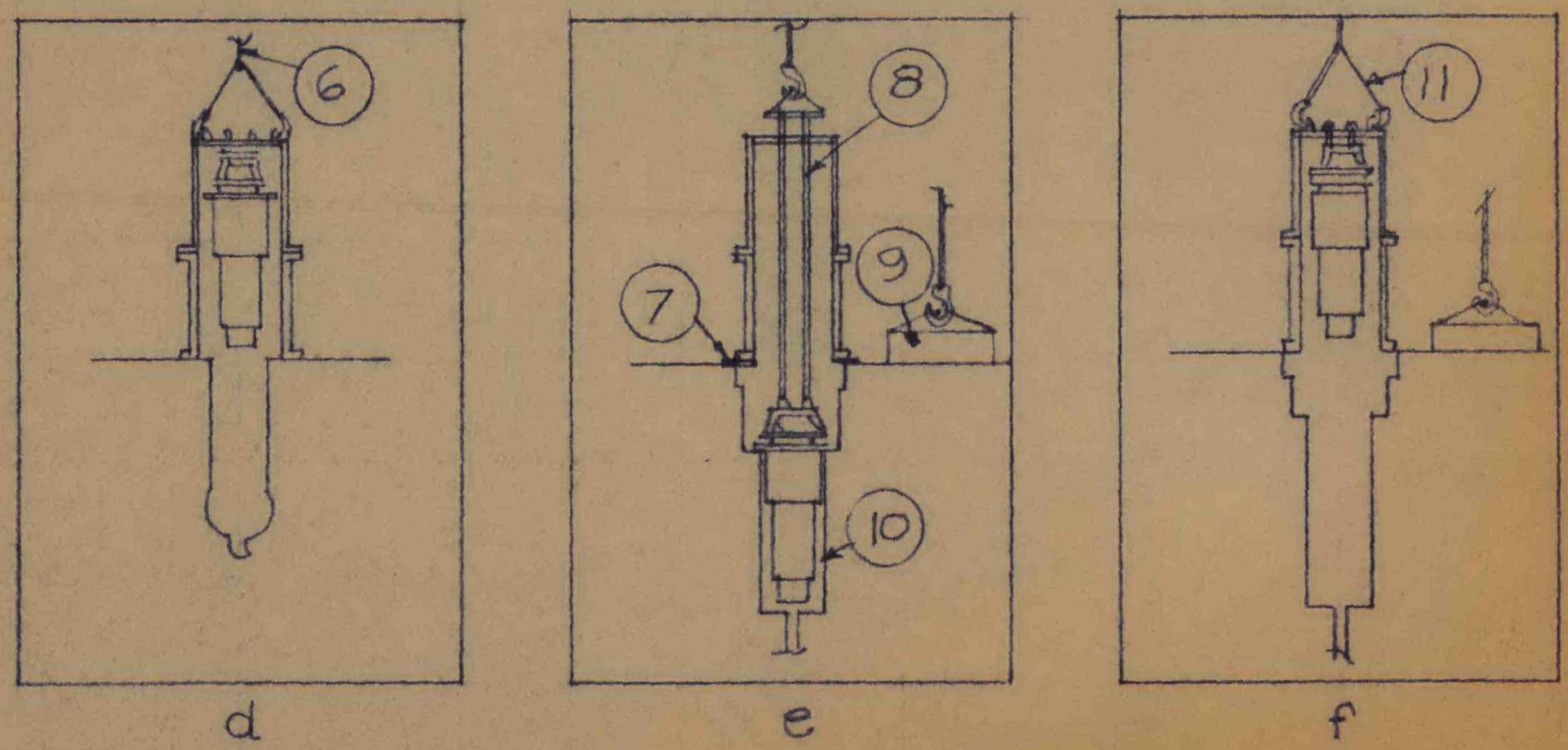

FIGURE 1 - PRIMARY PUMP REMOVAL $6-7$ 


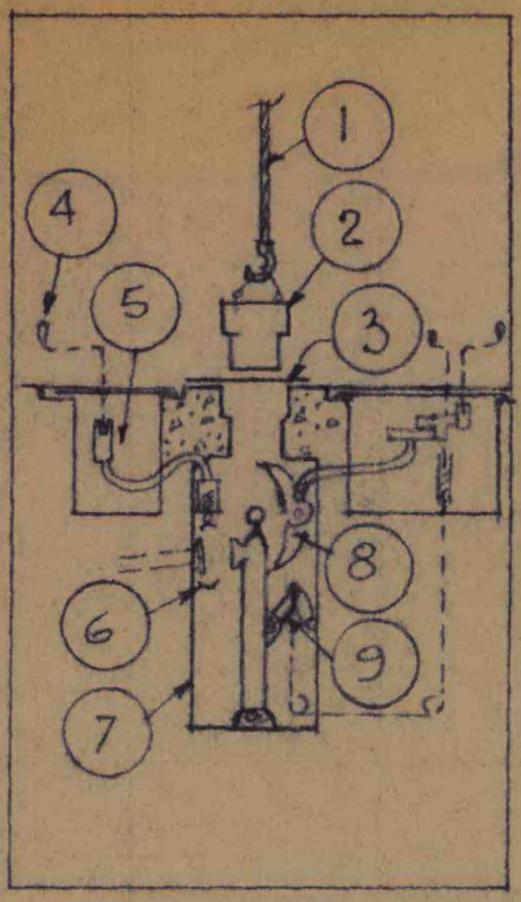

a

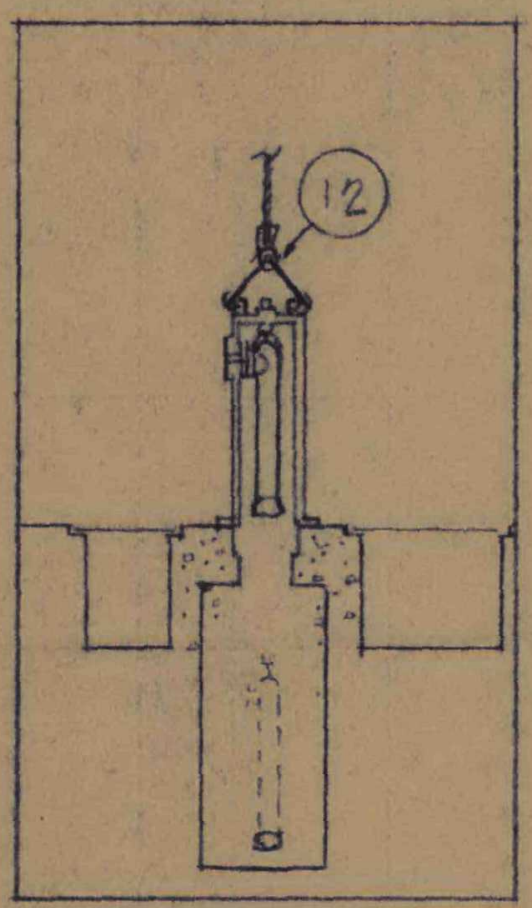

C

\section{LEGEND}

1- CRANE

2- CELL PLUG

3-COVER SHEET (PIT)

4-CRANK TOOL

5- FLEX. SHAFT

6-MARMAN CLAMP

7-CELL

8- CLAM SHELL SHIELD

9-TILT TOGGLE 10-CASK

11-MAGNETIC SHEET

12. CASK HOIST

13-STORAGE CELL PLUG 14-STORAGE CELL

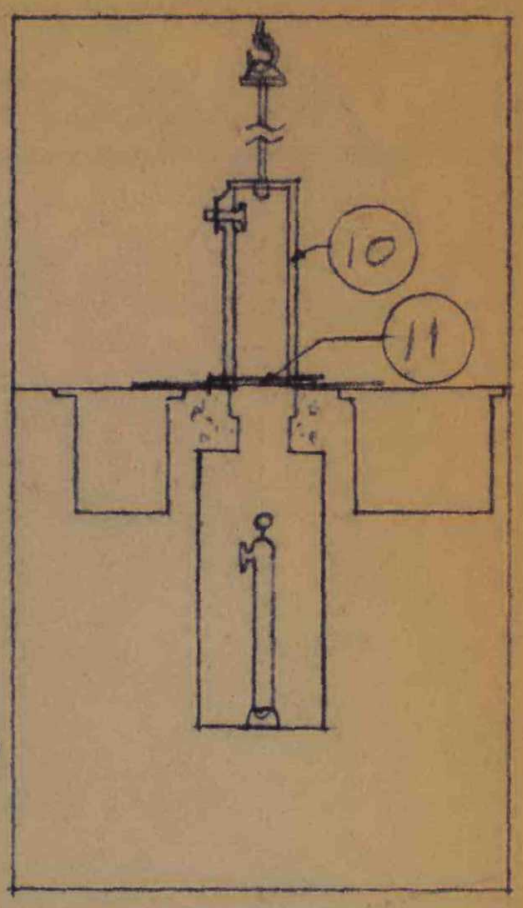

$b$

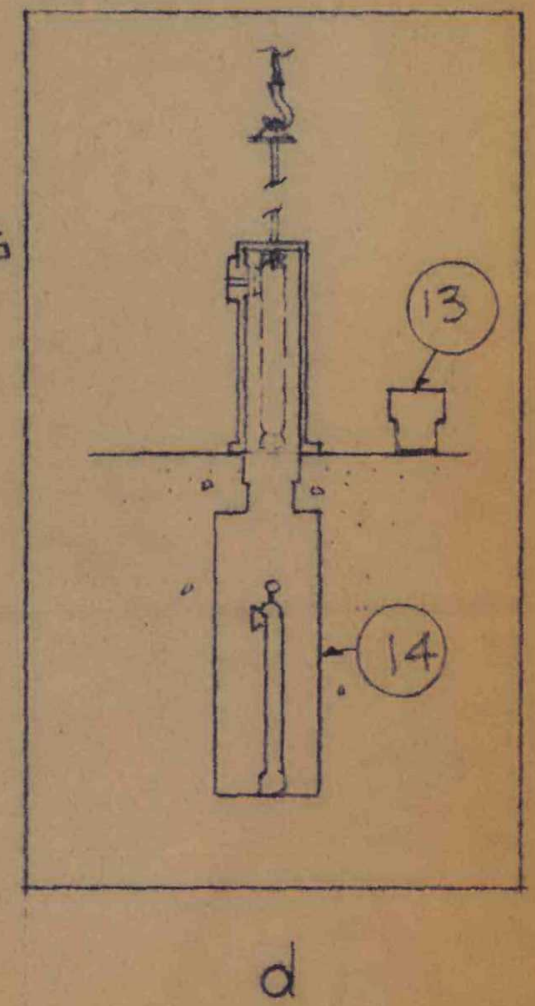

FIGURE 2 - COLD TRAP HANDLING 